\title{
A Therapeutic Concept by "Watted" for the Surgical Lengthening of the Lower Face by Short Face Syndrome
}

\author{
Nezar Watted ${ }^{*}$, Muhamad Abu-Hussein ${ }^{2}$, Josip Bill ${ }^{3}$, Peter Proff ${ }^{4}$ \\ ${ }^{1}$ Department of Orthodontics, Arab American University, Jenin, Palestine \\ ${ }^{2}$ Department of Pediatric Dentistry, University of Athens, Athens, Greece \\ ${ }^{3}$ Clinic for Cranio-Maxillo-Facial Surgery, Würzburg, Germany \\ ${ }^{4}$ Department of Orthodontics, University of Regensburg, Regensburg, Germany \\ Email: nezar.wattted@gmx.net
}

Received 4 December 2014; accepted 7 May 2015; published 12 May 2015

Copyright (C) 2015 by authors and Scientific Research Publishing Inc.

This work is licensed under the Creative Commons Attribution International License (CC BY).

http://creativecommons.org/licenses/by/4.0/

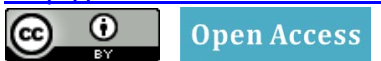

\section{Abstract}

The continuously growing esthetic awareness for the facial appearance and the spreading of information about the possibilities of adult treatment by public media result in an increase of adult patients which seek orthodontic treatment to improve their facial esthetics. In general, these patients show such a severe skeletal deformity that it is detectable even by non-experts because of its extraoral manifestation, which is the main motivation for treatment. Because of the nature of these deformities and because of the lacking growth usable for therapy the only promising treatment for these patients is the combined orthodontic-surgical approach. Besides a stable and functional occlusion with physiologic position of the condyle, the goals of treatment are the improvement of the dental and, above all, facial esthetics since the patient judges the success of treatment mostly by the extraoral appearance. The dentofacial appearance must be defined prior to treatment to plan the individual right approach in knowledge of the different treatment possibilities for Angle Class II deformities and thus be able to reach for both sides-patient and orthodontistsatisfying result. With this article, a systematic therapy concept to treat patients with Class II deformities and skeletal deep bite with a short lower face (short face syndrome) under consideration of the soft tissue analysis is presented.

\section{Keywords}

Cephalometrics, Facial Proportions, Lower Face Height, Skeletal Deep Bite, Short Face Syndrome, Lengthening of the Lower Face, Bilateral Sagittal Split Osteotomy, Mandibular Advancement, Splint

${ }^{*}$ Corresponding author.

How to cite this paper: Watted, N., Abu-Hussein, M., Bill, J. and Proff, P. (2015) A Therapeutic Concept by "Watted" for the Surgical Lengthening of the Lower Face by Short Face Syndrome. Open Journal of Stomatology, 5, 127-141. 


\section{Therapy, Lateral Open Bite}

\section{Introduction}

Dentoalveolar compensations can mask or correct a great number of minor deformities, but extensive sagittal corrections require more aggressive measures. Depending upon the extent of the problem and the timing, treatment modalities for Class II correction could be:

1) A causative approach in the form of influencing the growth components. Functional appliances for the ventral development of the mandible and simultaneous growth inhibition of the maxilla in the sagittal and vertical direction can be used [1]-[7].

2) Manipulation of the dentoalveolar complex to gain space. The overjet can be reduced by distalisation of first molars into Class I followed by retraction of anterior teeth [8]-[10].

3) Space gaining by extraction. Either all four premolars or just two maxillary premolars can be extracted in order to achieve a functional occlusion with Class I canine relationship [11].

4) Orthognathic surgery to address the skeletal deformity if the treatment goals cannot be reached with first three possibilities listed above [12]-[14].

In order to employ any of these above alternatives the correct diagnosis must be made followed by case-specific treatment goals. Individualized treatment plan is based on studies of records such as facial photographs, panoramic radiographs, cephalograms, functional analysis, casts along with the assessment of patient's motivation for treatment.

\section{Patients' Motivation for Orthodontic or Sugical Treatment}

Numerous reports of patient motivation for orthodontic treatment can be found in the literature. Many of these studies investigate the impact of variables such as age, gender or social status on patients' decision to seek treatment. It appears that the motivation and satisfaction factors vary among the individuals. For example, studies of Flanary [15], Jacobson [16] and Kiyak [17] with respect to motivation, expectation and satisfaction show that $79 \%$ to $89 \%$ of the patients [18] [19] who were treated with orthognathic surgery received this form of treatment for esthetic reasons rather than functional. Moreover, their motivation for treatment was driven by the extent of the facial deformity. Kiyak also found that more women than men articulated their wish to improve their facial esthetics. It is noteworthy that patients after orthognathic surgery value esthetic motivations much higher than before, in contrast to functional factors [20]. The orthodontist must formulate a set of treatment goals to fulfill the optimal functional and esthetic demands of the individual. A purely occlusion oriented therapy may not be necessarily conducive to a facially esthetic satisfying result. A comprehensive analysis of the facial soft tissue relationships therefore, is key to optimal treatment. Patients judge the treatment result primarily by the improved extraoral appearance [5] [15]-[19] [21]-[26].

\section{Harmonic Relations of the Face}

In the esthetic face the three vertical elements are distributed harmoniously. The total facial height (Trichion or hairline to soft tissue Menton; T-Me') is composed of 1/3 upper-(Trichion-Glabella; T-G'), 1/3 mid-(GlabellaSubnasal; G'-Sn) and 1/3 lower face (Subnasal-soft tissue Menton, Sn-Me') [12] [13] [27]-[34] (Figure 1(a), Figure 1(b), Figure 2(a), Table 1). Some authors describe the proportions as follows: The mid-face accounts for $47 \%$ (soft tissue Nasion-Subnasale) and the lower face (Subnasale-soft tissue Menton) for $53 \%$ of the face height [35]. In the harmonic lower face (Subnasal-soft tissue Menton; Sn-Me') there is a ratio of 1:2 between the distances from Subnasale-Stomion (Sn-Stm) to Stomion-soft tissue Menton (Stm-Me') (Figure 2(b), Table 1).

A harmonious soft tissue relationships is a reflection of the harmony of the underlying skeletal structures. This was described by Burstone in 1958 [27] and later modified by Legan and Burstone [33]. The skeletal mid face (N-Ans) is made of $45 \%$ and the lower face (Ans-Me) of 55\% (Figure 2(c), Table 2).

\section{Problem}

The above-described harmonic division of the face can be disturbed by a variety of factors. A disharmony of the 
skeletal structures can, but not necessarily, influence the soft tissue profile. Understanding this fact is critical to analysis, diagnosis and treatment planning. The harmony of facial relations is disturbed in the Class II short-face syndrome patient. The skeletal lower face, thus the vertical soft tissue profile, shows a deficiency in the midface [12] [13] [28] [33] [36]-[38] (Figures 3(a)-(c), Table 3). The short lower face is caused by an anterior rotation of the mandible and a reduced interbase angle (skeletal deep bite). The anterior rotation of the mandible is often combined with a small Gonial angle. The characteristic consequence of the short lower face is an increased ratio of posterior to anterior face height. (Figure 4, Table 4). The short lower face is the primary esthetic concern to the patient [25], and is the main reason why they opt for a combined orthodontic surgical treatment.

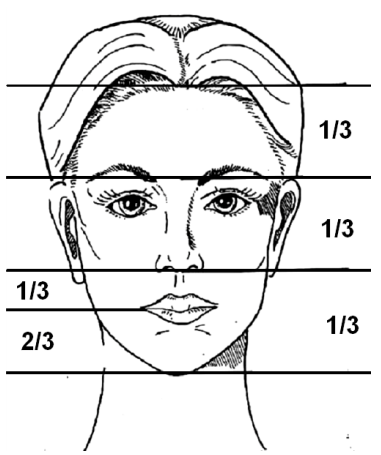

(a)

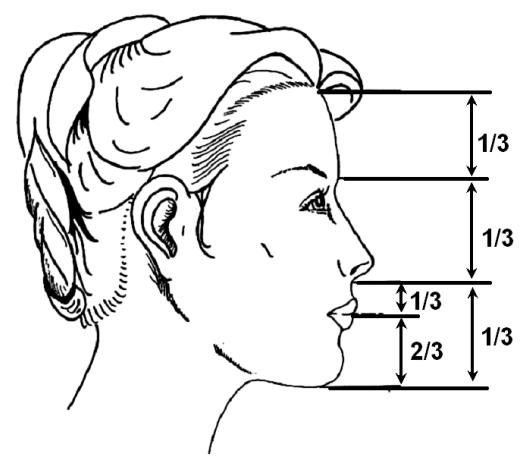

(b)

Figure 1. Division of the face between Trichion or Glabella and soft tissue Menton on the facial photograph. These proportions constitute the harmonic division of the face-the relation of the thirds is 1:1:1. The classification is defined by the hairline or Trichion (T) to Glabella, Glabella to Subnasal (Sn) and Subnasal to soft tissue Menton (Me').

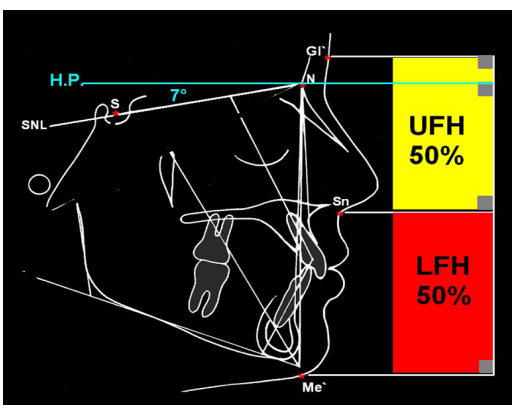

(a)

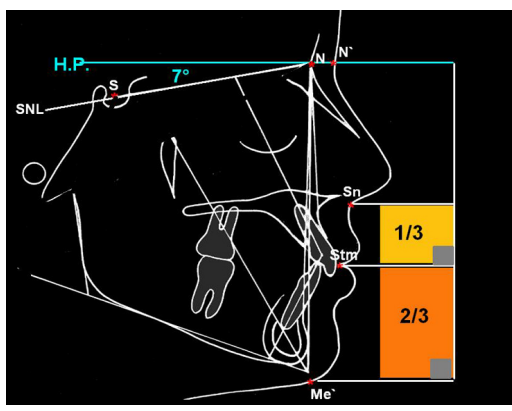

(b)

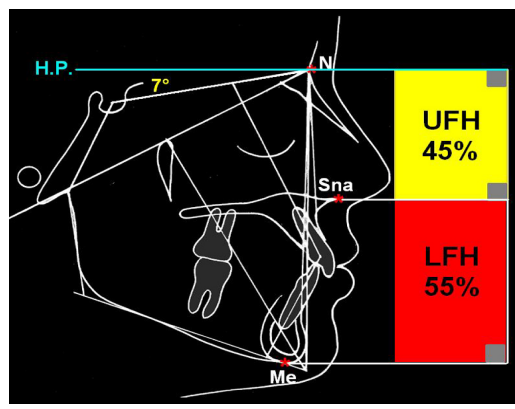

(c)

Figure 2. (a) The vertical division of the face between $\mathrm{G}^{\prime}$ and $\mathrm{Me}$ ' in the cephalogram with respect to the horizontal plane (HP); the harmonic relation of upper face height (UFH, G'-Sn) to lower face height (LFH, Sn-Me') is 1:1; (b) Vertical division of the lower face (Sn-Me'). The ratio of upper lip (Sn-Stm or Stms) to lower lip and the chin (Stm or Stms-Me') is 1:2 in rest position; (c) Skeletal division of the face in the vertical dimension, the relation of mid- to lower face with respect to Anterior nasal spine (N-Ans:Ans-Me) is $45 \%$ to $55 \%$.

Table 1. Proportion of the soft tissue structures.

\begin{tabular}{cc}
\hline Variable & Average or Ratio \\
\hline T-G':G'-Sn:Sn-Me' & $1: 1: 1$ \\
G'-Sn/G'-Me' & $50 \%$ \\
Sn-Me'/G'-Me' & $50 \%$ \\
N'-Sn/N'-Me' & $47 \%$ \\
Sn-Me'/N'-Me' & $53 \%$ \\
Sn-Stm/Stm-Me' & $1: 2$ \\
Sn-Li/Li-Me' & $1: 0.9$ \\
\hline
\end{tabular}


Table 2. Average value or proportion of the skeletal structures.

\begin{tabular}{cc}
\hline Variable & Average or Ratio \\
\hline ML-SNL & $32^{\circ}$ \\
NL-SNL & $8.5^{\circ}$ \\
ML-NL & $23^{\circ}$ \\
Gonion-< & $130^{\circ}$ \\
SN-PG & 81 \\
PFH/AFH & $63 \%$ \\
N-Ans/N-Me & $45 \%$ \\
Ans-Me/N-Me & $55 \%$ \\
\hline
\end{tabular}

Table 3. Ratios of the soft tissue structures before and after treatment.

\begin{tabular}{ccc}
\hline Variable & Before Treatment & After Treatment \\
\hline G'-Sn/G'-Me' & $56 \%$ & $50 \%$ \\
Sn-Me'/G'-Me' & $44 \%$ & $50 \%$ \\
Sn-Stm/Stm-Me' & $1: 2.3$ & $1: 2$ \\
Sn-Li/Li-Me' & $1: 0.8$ & $1: 1$ \\
\hline
\end{tabular}

Table 4. Average values or ratios of skeletal structures before and after treatment.

\begin{tabular}{ccc}
\hline Variable & Before Treatment & After Treatment \\
\hline ML-SNL & $22.5^{\circ}$ & $27^{\circ}$ \\
NL-SNL & $9.5^{\circ}$ & $9.5^{\circ}$ \\
ML-NL & 13 & $17.5^{\circ}$ \\
Gonion- & $115^{\circ}$ & $122^{\circ}$ \\
SN-Pg & $81.5^{\circ}$ & $83.5^{\circ}$ \\
PFH/AFH & $73 \%$ & $69 \%$ \\
N-Ans/N-Me & $49 \%$ & $45 \%$ \\
Ans-Me/N-Me & $51 \%$ & $55 \%$ \\
\hline
\end{tabular}

Possible symptoms of the short-face-syndrome are:

1) Short lower face, dominant chin and an increased mentolabial sulcus (Figures 3(a)-(c), Figure 4).

2) The cephalometric parameters show a small mandibular plane-interbase angle, the ratio of posterior to anterior face height (PFH/AFH) is increased. There is a discrepancy of the soft tissue harmony of upper to lower face. (Figure 4, Table 3, Table 4).

3) Intraorally one can detect a distal occlusion, deep bite, supraocclusion of the lower anteriors and a deepened curve of Spee (Figures 5(a)-(d)).

Thus in general, the goals of orthodontic treatment are:

1) Esrablishment of a Class I, stable and functional occlusion with physiologic position of the condyles.

2) Improvement of the facial esthetics.

3) Improvement of the dental esthetics within the framework of the periodontal health.

4) Stability of the result.

5) Fulfill the expectations and satisfy the patient. 


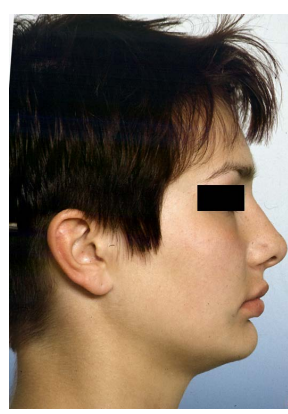

(a)

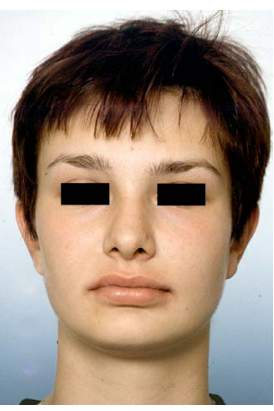

(b)

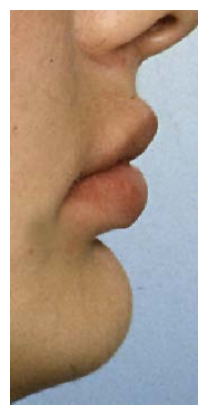

(c)

Figure 3. Lateral and frontal facial photograph picture of a Class II patient with short-face-syndrome, short lower face, deepened sublabial sulcus with prominent lower lip and chin.

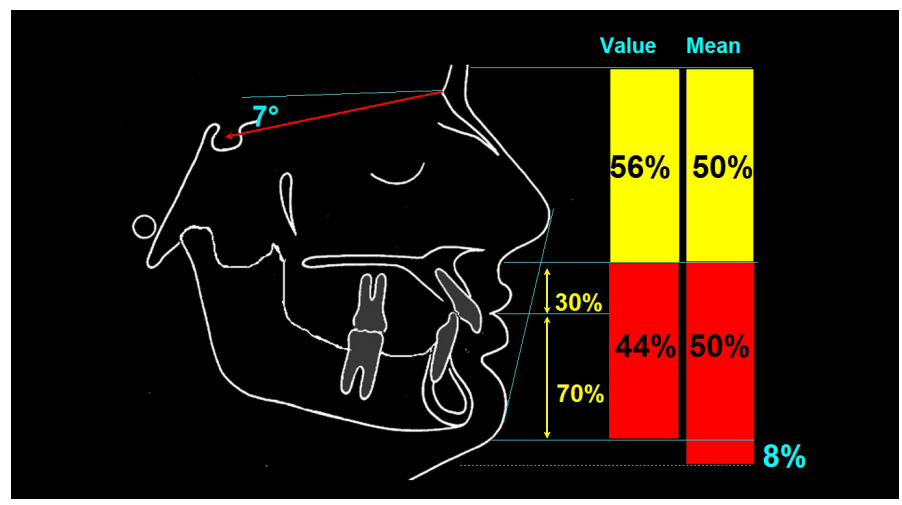

Figure 4. Disharmonic vertical proportions of the soft tissue profile of upper face ( $\left.\mathrm{G}^{\prime}-\mathrm{Sn}\right)$ to lower face (Sn-Me'). The lower face shows a deficit of $8 \%$ compared to the upper face. There is a disharmony of the proportions of the lower face as well.

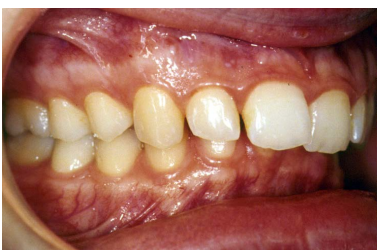

(a)

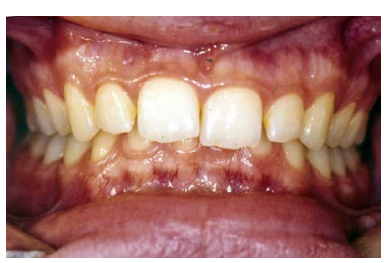

(b)

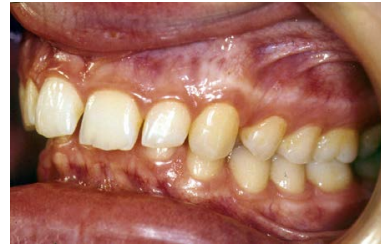

(c)

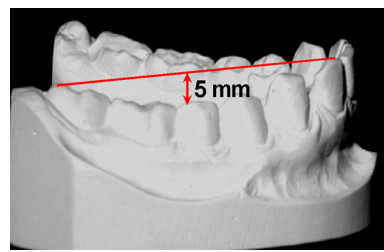

(d)

Figure 5. (a)-(c) Intraoral view shows a distal occlusion, deep bite and malpositioned teeth; (d) A deep curve of Spee (5 $\mathrm{mm}$ ) results from a supraocclusion of the lower anteriors, a typical symptom in patients with skeletal deep bite.

Special attention must be paid to some critical aspects of treatment in the short-face syndrome patient. The improvement of the facial esthetics is not only related to the sagittal but also to the vertical dimension. This means that in the short-face syndrome patients, a lengthening of the lower face should be reached without increasing the chin prominence. A lengthening of the lower face as causal therapy with corresponding effects on the facial esthetics can only be accomplished with a combined orthodontic-orthognathic surgery procedure where the Gonial angle and thus the interbase angle is increased [38]-[40]. Surgical enlargement of the mandibular plane angle harmonizes the ratio of posterior to anterior face height.

\section{Solution and Concept of Therapy}

These above-established treatment goals are reached decisively with surgery. The necessary lengthening of the lower face is achieved by the translation or rotation of the tooth-bearing segment of the mandible during surgery. 
The orthodontist plans and controls the extent of these movements [39] [40]. Prerequisite for the stability of the enlarged gonial angle by this move, is a three-point support at the incisors and molars at the time of the surgery. Mandible can be rotated posteriorly only when the lower front teeth are in contact with the palatal surfaces of the maxillary incisors. Once the incisors are occluded, the skeletal correction is accomplished by a clockwise rotation of the mandible. This maneuver increases the lower face height and enlarges the gonial angle (Figures 6(a)-(c), Figure 7, Figure 8). Although the mandible is displaced anteriorly, the chin prominence is accentuated only a little because the posterior rotation compensates for the ventral movement, which in these patients is an advantage. The flattening of the sublabial sulcus can also be observed (Figures 6(a)-(c), Figure 8).

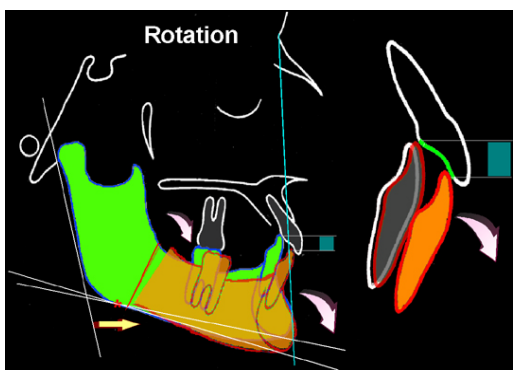

(a)

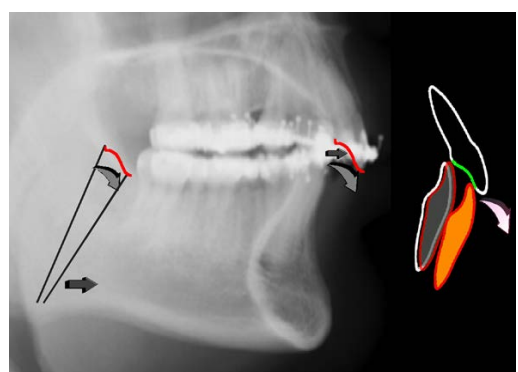

(b)

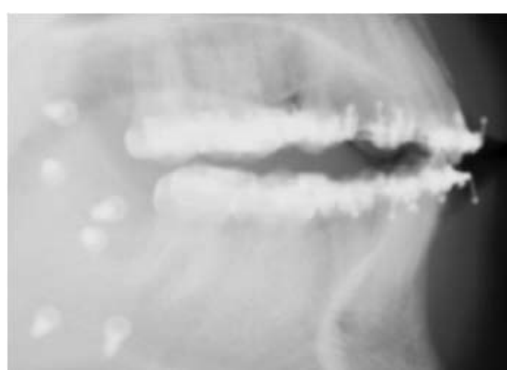

(c)

Figure 6. (a) Simulation of the surgical advancement without leveling the lower dental arch. By surgical rotation of the mandibular segment there is an opening of the Gonial angle. The vertical plumb line touches Pogonion in the presurgical situation and shows a minor ventral advancement of the chin prominence; (b) Cephalogram prior to surgical advancement of the mandibular segment; a rotation of the mandibular segment follows the palatal surfaces of the upper anteriors; (c) Cephalogram after surgical advancement of the mandibular segment, lateral open bite with 3-point contact on the anteriors and molars after the posterior rotation.

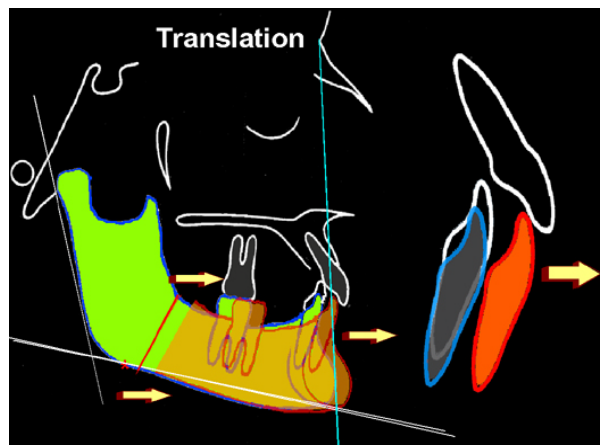

Figure 7. Simulation of a surgical advancement of the mandibular segment with leveling of the lower dental arch prior to surgery. It results in the correction of the sagittal disharmony without changing the vertical relation and an esthetically compromised outcome because of the more prominent chin.

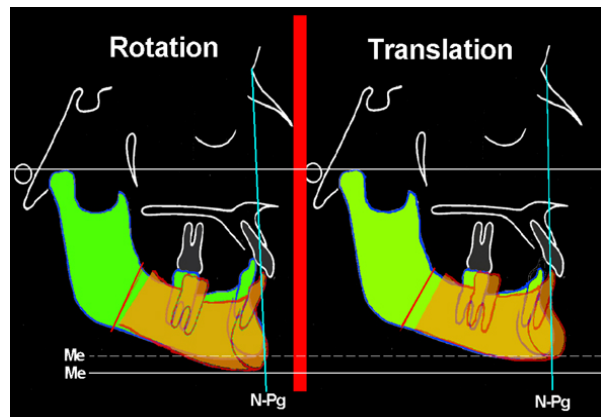

Figure 8. Demonstration of the sagittal and vertical changes after surgical advancement with and without leveling of the lower dental arch. 
A straightforward advancement of the mandible when the curve of Spee is leveled, might correct the sagittal discrepancy, but not the vertical; chin will become prominent, and the face concave. It will then be necessary to perform genioplasty (Figure 7, Figure 8). Another important aspect in mandibular advancement is the stretching of the suprahyoid muscles. they have been (especially digastric) suggested to cause relapse; the greater the translation the larger the stretching or strain on these muscles (Figure 9). Rotation minimizes this effect (Figure 10). Carlson [41] and Reynolds [42] showed in the primates that mandibular advancement produces stretching and strain on the soft tissue of the suprahyoid complex. Concurrently, forces are produced to pull the mandibular segment dorsally. Ellis too reported on the posterior positioning of the condyle following the surgical advancement of the mandible [43]. The postsurgery posterior position is supposed to be a result of these muscle forces in the dorsal direction. In all these studies the advancement of the mandible was performed without taking the strain on the muscles into account. Our approach to treatment of short-face syndrome patients at the University of Würzburg [39] [40] avoids stretching of these muscle fibers. Typically, we take the following steps in treatment:

1) Pre-surgery measures and orthodontic setup:

- Splint therapy to establish the centric relation for final treatment planning.

- Orthodontics to adjust the dental arches to each other and to decompensate the skeletal deformity.

- Splint therapy to establish the centric relation 4 - 6 weeks prior to surgery.

2) Surgery to correct the skeletal deformity.

3) Orthodontics for finishing the occlusion.

4) Retention to stabilize the result.

\subsection{Pre-Surgery Measures and Orthodontic Setup}

\subsubsection{Splint Therapy to Establish the Centric Relation for Final Treatment Planning}

It is often necessary to insert an initial splint in these patients either for the treatment of temporomandibular joint

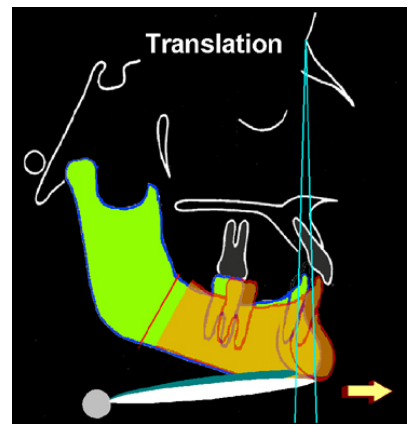

Figure 9. Demonstration of the effects of the different advancements: The rotation results in a minimal stretching of the digastric muscle.

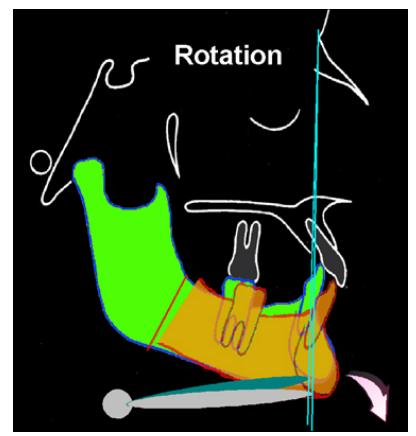

Figure 10. Demonstration of the effects of the different advancements: The rotation results is rather extensive with translation. 
problems or for diagnostics [44]-[49]. Celenza [50]-[52] and Calagna et al. [53] have showed that by tiring the muscles with a splint, the mandible could be retruded more than the hinge-axis position. In Class II div.1 patients a ventral positioning of the mandible is normally observed. Habitually, these patients protrude the mandible to make lip-closure possible. If there is a discrepancy of centric occlusion and centric position of the condyles (centric relation) after splint therapy, all diagnostic records (cephalograms, facial photographs, study casts and articulated casts) need to be re-taken in centric relation to be able to set up the final treatment plan [38]-[40] (Figures 11(a)-(c)).

\subsubsection{Orthodontic Preparation}

The aim of the orthodontic preparation is to align the dental arches, harmonize in three dimensions of space and to eliminate the dental compensations. Special care must be taken for the transversal dimension at the canines to prevent premature contacts during surgery-it forces the mandible distally. The upper dental arch in Class II deformities usually shows a deficit in the transversal dimension relative to the lower arch. The correction of this discrepancy by widening the upper arch can be impeded or even made impossible when there is a stable occlusion (Figure 12(a), Figure 12(b)). Splint therapy deprograms the occlusion. In the short-face syndrome patients the lower arch is not leveled prior to surgery so that the curve of Spee and the deep bite is left uncorrected. For this purpose arch wires with corresponding bends are inserted (Figures 13(a)-(d)). Leveling of the lower arch by

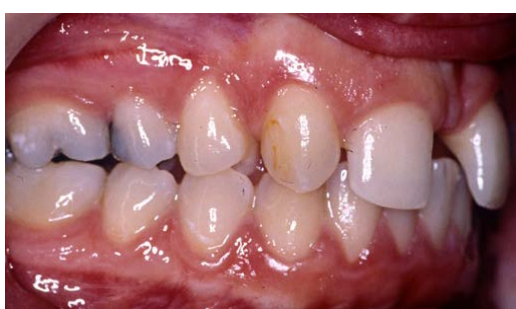

(a)

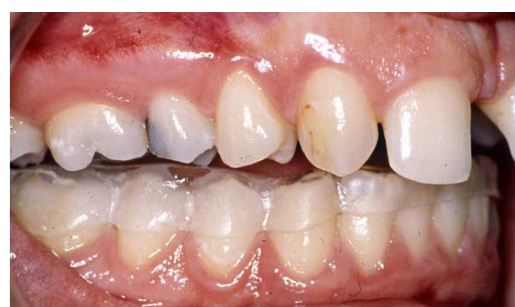

(b)

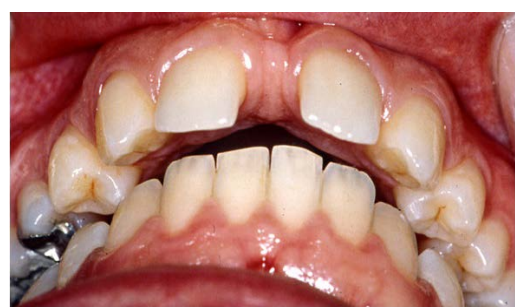

(c)

Figure 11. (a) Intraoral view of the centric occlusion in a 25-year old patient prior to insertion of a plane splint; (b) Inserted plane splint; (c) Situation after 4 weeks of insertion of the plane splint to locate the centric relation prior to the orthodontic treatment planning; increased overjet.

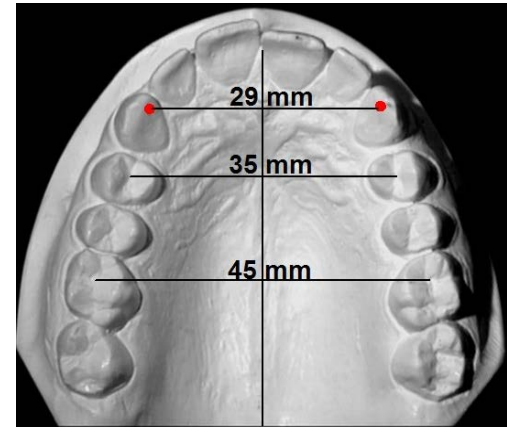

(a)

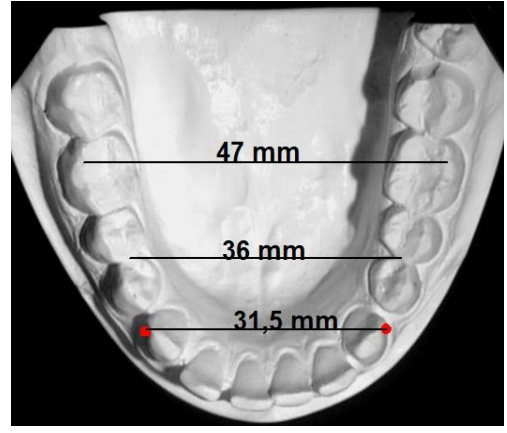

(b)

Figure 12. Discrepancy of corresponding points of occlusion of the canines in the upper $(29 \mathrm{~mm})$ and lower dental arch (31.5 mm).

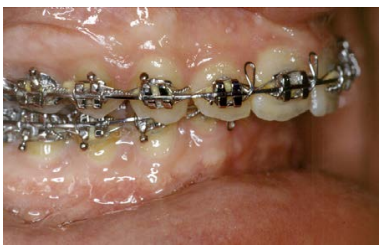

(a)

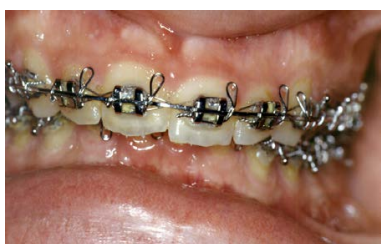

(b)

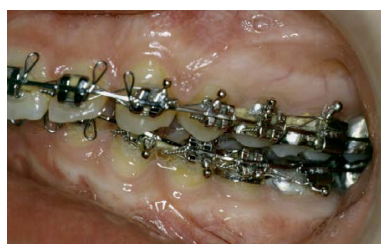

(c)

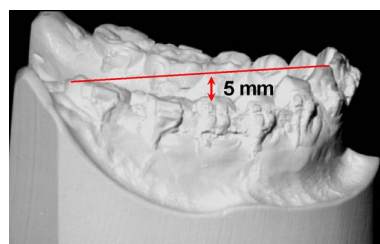

(d)

Figure 13. Clinical situation after orthodontic preparation. Deep bite (a)-(c) and curve of Spee (d) are almost unchanged. 
incisor intrusion increases the overjet. In turn, mandible requires greater advancement at the expense of rotational movement. In the event teeth have compensated for the skeletal deformity, and the curve of Spee nonexistent, extrusion of the lower anteriors might be necessary [39] [40].

\subsubsection{A Second Splint Therapy to Establish the Centric Relation 4 - 6 Weeks Prior to Surgery}

The aim of this procedure is to register a physiologic position of the condyle (centric relation) [44]-[47]. An inaccurate position of the mandible results in an incorrect planning of the amount of advancement and with that in an inevitable relapse.

\subsection{Surgery to Correct the Skeletal Deformity}

The surgical advancement is performed via a sagittal split osteotomy [54]-[58]. The centric positioning of the condyle during orthognathic surgery is a standardized procedure to keep the correct position of the condyles [14] [59]-[62] (Figure 14).

\subsection{Post-Surgial Orthodontics}

As a consequence of the posterior rotation of the segment with 3-point contact, a lateral open bite forms, and requires early correction (Figure 15(a), Figure 15(b)). Thus, early application of orthodontic forces after surgery is crucial. Generally on the $4^{\text {th }}$ postoperative day, post surgical orthodontics is instigated to close the lateral open bite without losing skeletal height, and at the same time to put the finishing touches and to stabilize and occlusion.

According to our concept, the open bite should be corrected by extrusion of the upper posterior teeth only and not by intrusion of the anteriors. The closure of the lateral open bite is done in two phases:

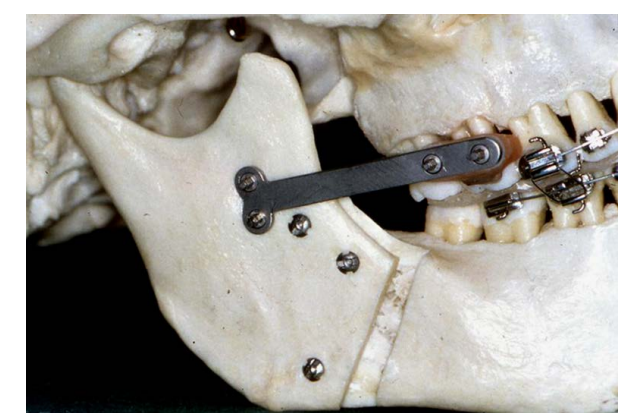

Figure 14. Positioning of the condyle prior to the sagittal split of the mandible.

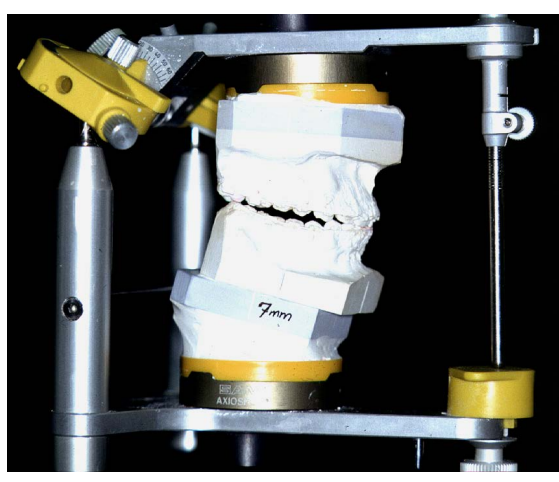

(a)

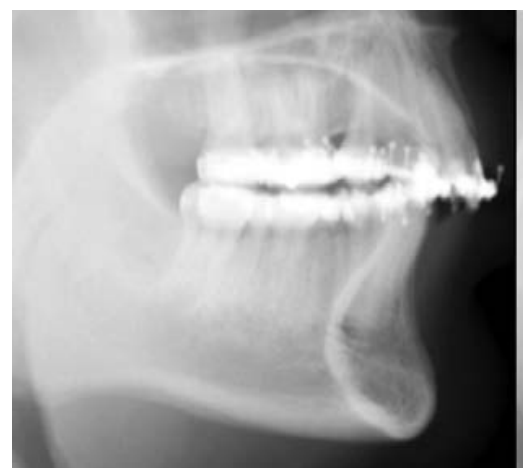

(b)

Figure 15. (a) Planning casts in the articulator; advancement with posterior rotation of the segment shows a lateral open bite; (b) Cephalogram prior (left) and after surgical advancement of the mandibular segment and its rigid fixation with screws (right); consequence of the advancement with posterior rotation of the segment with three point contact is a lateral open bite. 
1) The maxillary steel archwire is replaced by $0.018 \times 0.025 \mathrm{NiTi}$. Extrusive bends for the premolars and the first molar are incorporated in this archwire and vertical elastics are used to augment the extrusive effect while minimizing the intrusive reaction to the remaining teeth. The elastics are placed in such a manner that one tooth in the upper jaw and two teeth in the lower jaw are loaded. Some days later, the extrusive step in the open bite area - mostly the first or second premolar-is increased, and the elastic use continued (Figures 16(a)-(c)).

2) After the NiTi-wire is passive in the upper jaw a NiTi wire replaces the lower steel archwire. Again, up-and-down elastics are used to close the residual open bite by extrusion of the premolars, and as little as possible by intrusion of the anterior teeth. Now one tooth in the lower is loaded against two teeth in the upper jaw (Figure 17).

\subsection{Retention}

Following surgery reorientation of skeletal parts by the muscle pull could be a significant problem for the soft tissues balance. This strain on the muscles is reduced significantly by rotation of the mandible as described above. To allow the muscles to adapt to the new situation, we suggest a bimaxillary appliance for retention e.g., a bionator. The construction bite must be taken with teeth only slightly disoccluded. If the mandibular advancement was significant, especially in patients with tense or short muscles of the suprahyoid complex, a physiotherapeutic treatment is prescribed to rehabilitate and reorient the muscles to their new positions. Furthermore, a bonded canine to canine retainer might be recommended, especially in patients with severely malposed teeth prior to treatment.

\section{Treatment Results}

Treatment results are assessed as follows:

\section{Cephalometrics:}

Posterior rotation increased the Gonion angle by $7^{\circ}$, which resulted in an increased interbase angle (ML-NL). Consequently, the upper and lower face were harmonized (N-Ans: Ans-Me or UFH:LFH $=45 \%: 55 \%$ ). The lengthening of the lower face increased the total face height and harmonized the posterior to anterior face

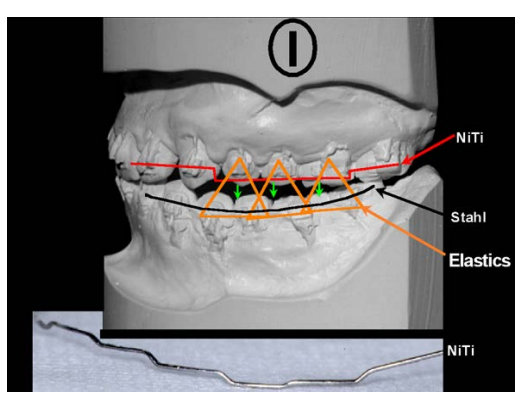

(a)

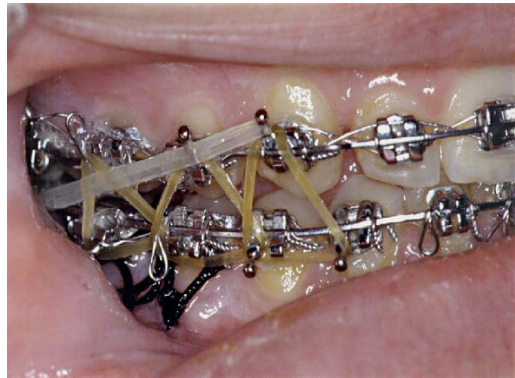

(b)

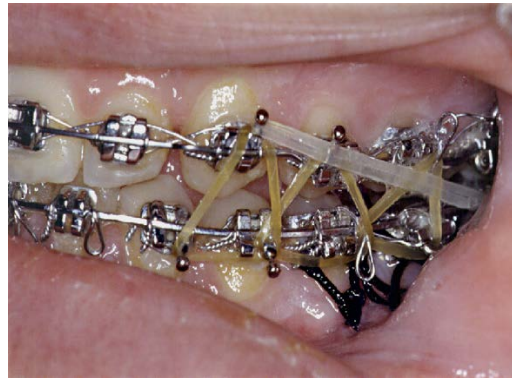

(c)

Figure 16. Phases to close the lateral open bite.

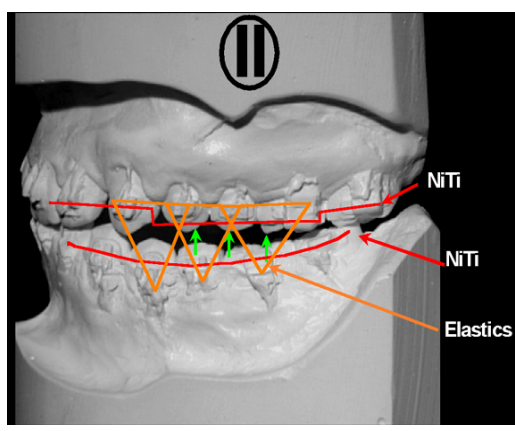

Figure 17. Mechanics to close the lateral open bite. 
$(\mathrm{PFH} / \mathrm{AFH}=69 \%)$. Pogonion $(\mathrm{Pg})$ was advanced only a little with the correction of the skeletal deformity which is reflected in the relatively small increase of the angle SN-Pg (Figure 18, Table 3, Table 4).

\section{Extraoral:}

The effects of skeletal correction on the soft tissue profile are depicted in Figures 19(a)-(d). The sagittal discrepancies are corrected without making the chin more prominent. The mentolabial sulcus was also reduced with the posterior rotation of the mandible.

\section{Intraoral:}

The intraoral pictures show a stable Class I occlusion (Figures 20(a)-(c)). The closure of the lateral open bite with the described extrusion mechanics supported by up-and-down elastics was achieved primarily by extrusion of the premolars and molars. The extrusive step is largest at the first premolar where the lateral open bite was broadest (Figure 21).

\section{Discussion}

Diagnostic records taken in a centric position of the condyle are of key importance in planning treatment for the orthognathic surgery patient. To ensure this position, deprogramming of the occlusion for a period (4 - 5 weeks) is necessary. This step is particularly important in Class II deformities with increased overjet as these patients

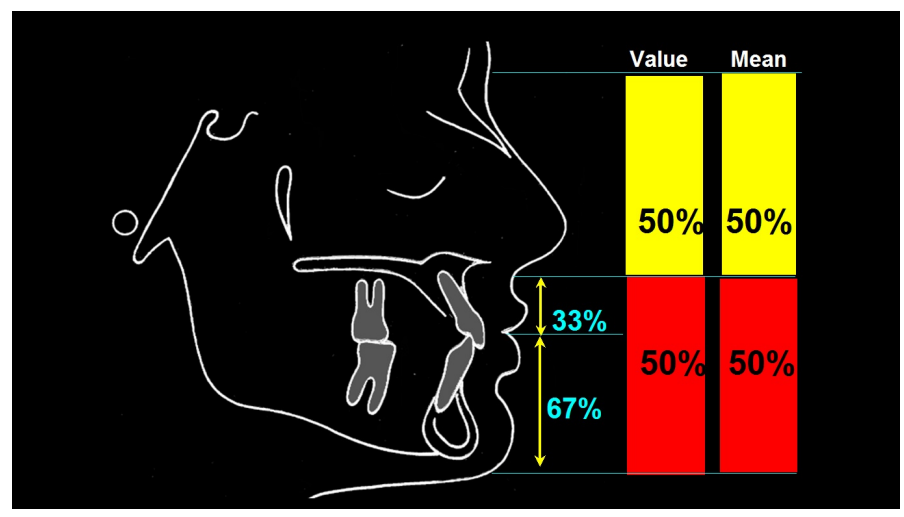

Figure 18. The cephalogram after treatment shows a harmonic relation of the soft tissue profile of upper to lower face; the proportions within the lower face are harmonized as well. A harmonization of the skeletal structures in the horizontal and in the vertical dimensions was achieved. An increase of the interplane angle (ML-NL) by surgical opening of the Gonial angle resulted in an increase of the posterior incline of the mandibular plane (ML-NSL; variables in table III and IV).

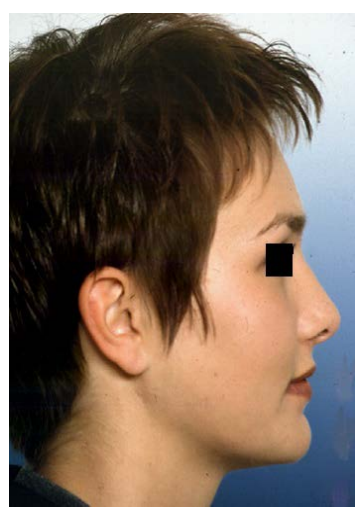

(a)

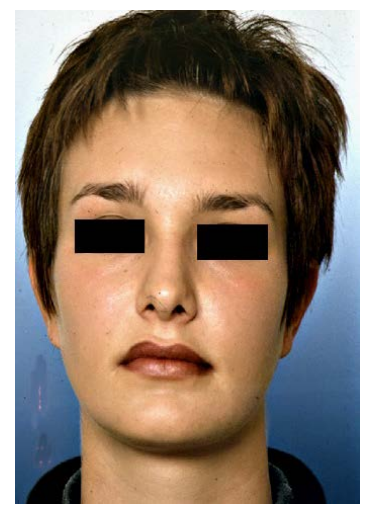

(b)

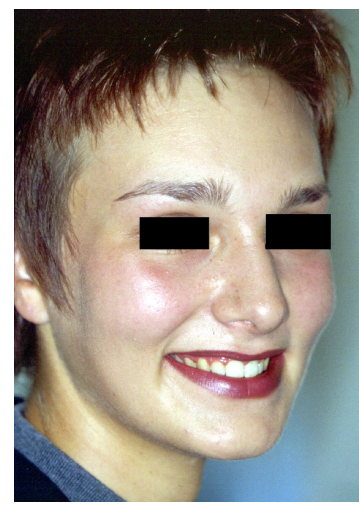

(c)

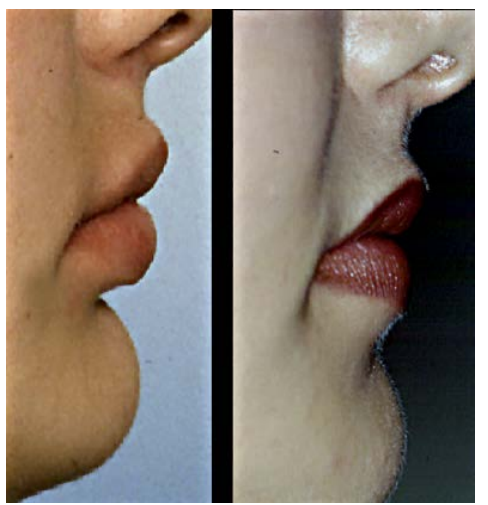

(d)

Figure 19. Extraoral appearance of treatment results. The sagittal deficit was corrected without increasing the chin prominence. At the same time the vertical dimension was harmonized. The sublabial sulcus was flattened. 


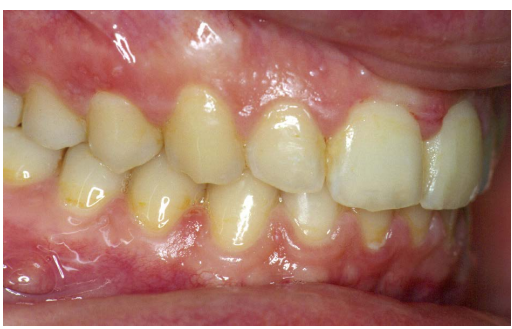

(a)

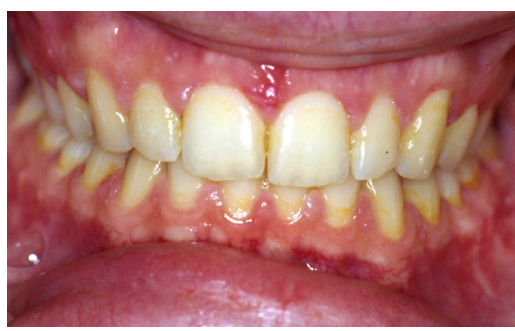

(b)

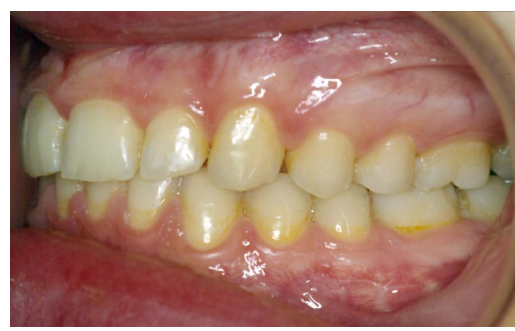

(c)

Figure 20. Class I and stable occlusion at the end of treatment.

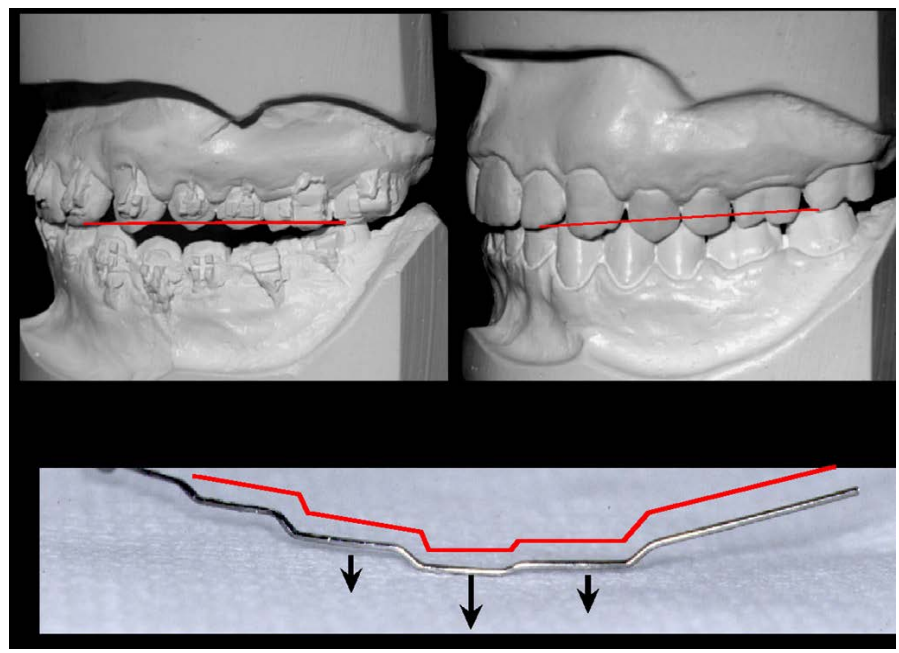

Figure 21. The casts show the surgical planning (left) and the situation after closure of the lateral open bite. The line drawn above the wire shows the extent of extrusion of the lateral teeth in the upper jaw with the corresponding bendings of the NiTi arch wire. The extrusive step is greatest in the region of the first premolar where the open bite is largest.

are known to habitually protrude for lip seal. Treatments planned without consideration of the condylar location in the fossa run the risk of inadequate advancement and post surgical setback of condyles in the fossa; oftentimes labeled as relapse [14] [42] [43] [59].

We demonstrate in this report that patients with the short-face-syndrome are best treated by posterior rotation of the mandible. The clinician is cautioned that leveling of the lower dental arch prior to surgery reduces the effectiveness of the surgical move. The leveled dental arch will force a straightforward advancement. As discussed earlier, without the rotational component, the chin becomes undesirably prominent. It may even stretch the suprahyoid muscles beyond their natural tolerance and elicit relapse.

From a dental perspective it is important to realize that labial tipping of the lower anteriors promotes posterior rotation of the mandibular segment during surgery. Naturally, the surgical rotation as described gives rise to a lateral open bite. The three-point-contact (molars and anteriors) could potentially overload the anterior teeth and can harm (root resorption) teeth. Thus, we advocate closure of the created lateral open bite as soon as possible following surgery. This can be done by extrusion of the buccal teeth and as little as possible by intrusion of the anterior teeth. A strategic plan for treatment based on the concepts outlined in this report, in our experience, ensures satisfactory facial esthetics and stability.

\section{Conclusion}

By means of the systematic treatment approach presented, class II deformities with a skeletal deep bite and short lower face can be treated with predictable success and without esthetic compromises. The treatment result shows 
that it is necessary to leave or to create a certain curve of Spee depending on the extent of the deformity to end with a satisfactory result with respect to function, esthetics and stability. The posterior rotation of the dental segment of the lower arch during surgery is essential to obtain the desired effect. It can be concluded that it is only possible to reach the preset treatment goals with an exact diagnosis and knowledge of the necessary orthodontic preparation in combination with the surgical procedure.

\section{References}

[1] McNamara Jr., J.A., McDougall, P.D. and Dierks, J.M. (1966) Arch with Development in Class II Patients Treated with Extraoral Force and Functional Jaw Orthodontics. American Journal of Orthodontics, 52, 353-359. http://dx.doi.org/10.1016/0002-9416(66)90152-7

[2] Petrovic, A.G. and Stutzmann, J. (1988) Reaktionsfähigkeit des tierischen und menschlichen Kondylenknorpels auf Zell-und Molekularebene im Lichte einer kybernetischen Auffassung des faszialen Wachstums. Fortschr Kieferorthop, 49, 405-425. http://dx.doi.org/10.1007/BF02341231

[3] Stutzmann, J. and Petrovic, A. (1987) Durch Bionator verursachtes zusätzliches Längenwachstum des Unterkiefers beim Kind. Fortschritte der Kieferorthopädie, 48, 556-558. http://dx.doi.org/10.1007/BF02164030

[4] Teuscher, U. (1976) Prinzipien Extraoraler Kräfte. Inf Orthod Kieferorthop, 7, 9-16.

[5] Watted, N. (1999) Behandlung von Klasse II-Dysgnathien-Funktionskieferorthopädische Therapie unter Berücksichtigung der dentofacialen Ästhetik. Kieferortopaedie, 13, 193-208.

[6] Witt, E. (1969) Muskelphysiologische Untersuchungen bei der Distalbißbehandlung mit dem Aktivator und Bionator. Schweiz Monatsschr Zahnmed, 79, 469-478.

[7] Witt, E. and Watted, N. (1999) Effectiveness of Intra- and Extraoral Aids to the Bionator. A Controlled Study within the Scope of the "Wuerzburg Concept". Journal of Orofacial Orthopedics, 60, 269-278. http://dx.doi.org/10.1007/BF01299785

[8] Armstrong, N.M. (1971) Controlling the Magnitude, Duration and Direction of Extra Oral Force. American Journal of Orthodontics, 59, 217-243. http://dx.doi.org/10.1016/0002-9416(71)90097-2

[9] Gianelly, A.A., Bendnar, J. and Dietz, V.S. (1991) Japanese NiTi Coils Used to Move Molars Distally. American Journal of Orthodontics and Dentofacial Orthopedics, 99, 564-566. http://dx.doi.org/10.1016/S0889-5406(05)81633-6

[10] Gianelly, A.A. (1998) A Strategy for Nonexraction Class II Treatment. Perspectives on Class II Treatment. Seminars in Orthodontics, 4, 26-32. http://dx.doi.org/10.1016/S1073-8746(98)80039-X

[11] Witt, E. (1988) Extraktion im Rahmen der Kieferorthopädie. In: Schmuth, G., Ed., Kieferorthopädie II, Praxis der Zahnheilkunde, Urban u. Schwarzenberg, München, 107-149.

[12] Arnett, G.W. and Bergmann, R.T. (1993) Facial Keys to Orthodontic Diagnosis and Treatment Planning Part I. American Journal of Orthodontics and Dentofacial Orthopedics, 103, 299-312. http://dx.doi.org/10.1016/0889-5406(93)70010-L

[13] Arnett, G.W. and Bergmann, R.T. (1993) Facial Keys to Orthodontic Diagnosis and Treatment Planning Part II. American Journal of Orthodontics and Dentofacial Orthopedics, 103, 395-411. http://dx.doi.org/10.1016/S0889-5406(05)81791-3

[14] Reuther, J. (1988) Kooperation zwischen Kieferorthopädie und Kieferchirurgie. Prakt Kieferorthop, 2, 177-186.

[15] Flanary, C.M., Barnwell, G.M. and Alexander, J.M. (1985) Patient Perceptions of Orthognathic Surgery. American Journal of Orthodontics, 88, 137-145. http://dx.doi.org/10.1016/0002-9416(85)90238-6

[16] Jacobson, A. (1981) The Influence of Children’s Dentofacial Appearance on Their Social Attractiveness as Judged by Peers and Lay Adults. American Journal of Orthodontics, 79, 399-415. http://dx.doi.org/10.1016/0002-9416(81)90382-1

[17] Kiyak, H.A., Hohl, T. and West, R.A. (1984) Psychological Changes in Orthognathic Surgery Patients: A 24-Month Follow-Up. Journal of Oral and Maxillofacial Surgery, 42, 506-512. http://dx.doi.org/10.1016/0278-2391(84)90009-0

[18] Albino, J.E. and Tedesco, L. (1994) Esthetic Need for Orthodontic Treatment. In: Melsen, B., Ed., Current Controversies in Orthodontics, Quintessence Publishing, Chicago, 11-24.

[19] Berscheid, E. and Gangestade, S. (1982) The Social Psychological Implications of Facial Physical Attractiveness. Clinics in Plastic Surgery, 9, 289-296.

[20] Witt, E. (1991) Möglichkeiten und Grenzen der kieferorthopädischen Behandlung Erwachsener. Fortschritte der Kieferorthopädie, 52, 1-7. http://dx.doi.org/10.1007/BF02168151

[21] Buss, D. (1994) The Strategies of Human Mating. American Scientist, 82, 289-296.

[22] Edgerton, M.T. and Knorr, N.J. (1971) Motivational Patterns of Patients Seeking Cosmetic (Esthetic) Surgery. Plastic 
and Reconstructive Surgery, 48, 551-557. http://dx.doi.org/10.1097/00006534-197112000-00005

[23] Hatfield, E. and Sprecher, S. (1986) Mirror...Mirror, Importance of Look in Everyday Life. State University of New York, Albany.

[24] Peck, H. and Peck, S. (1970) A Concept of Facial Esthetics. The Angle Orthodontist, 40, 284-318.

[25] Philips, C., Trentini, C. and Douvartzidis, N. (1992) The Effect of Treatment on Facial Attractiveness. Journal of Oral and Maxillofacial Surgery, 50, 590-594. http://dx.doi.org/10.1016/0278-2391(92)90439-7

[26] Philips, C., Tulloch, C. and Dann, C. (1992) Rating of Facial Attractiveness. Community Dent. Community Dentistry and Oral Epidemiology, 20, 214-220. http://dx.doi.org/10.1111/j.1600-0528.1992.tb01719.x

[27] Burstone, G.J. (1958) The Integumental Profile. American Journal of Orthodontics, 44, 1-25. http://dx.doi.org/10.1016/S0002-9416(58)90178-7

[28] Burstone, G.J. (1967) Lip Posture and Its Significance in Treatment Planning. American Journal of Orthodontics, 53, 262-284. http://dx.doi.org/10.1016/0002-9416(67)90022-X

[29] Carlotti, A.E., Aschaffenberg, P.N. and Schendel, S.A. (1986) Facial Changes Associated with Surgical Advancement of the Lip and Maxilla. Journal of Oral and Maxillofacial Surgery, 44, 593-596. http://dx.doi.org/10.1016/S0278-2391(86)80068-4

[30] Farkas, L., Bryson, W. and Klotz, J. (1980) Is Photogrammetry of the Face Reliable? Plastic and Reconstructive Surgery, 66, 346-355. http://dx.doi.org/10.1097/00006534-198066030-00004

[31] Farkas, L.G. (1981) Anthropometry of the Head and Face in Medicine. Elsevier/North Holland Inc., New York.

[32] Farkas, L.G. and Kolar, J.C. (1987) Anthropometry and Art in the Aesthetics of Women's Face. Clinics in Plastic Surgery, 14, 599-615.

[33] Legan, H.L. and Burstone, G.J. (1980) Soft Tissue Cephalometric Analysis for Orthognathic Surgery. Journal of Oral Surgery, 38, 744-751.

[34] Willmot, D.R. (1981) Soft Tissue Profile Changes Following Correction of Class III Malocclusions by Mandibular Surgery. British Journal of Orthodontics, 8, 175-181. http://dx.doi.org/10.1179/bjo.8.4.175

[35] Bell, W.H., Proffitt, W.B. and White, R.P. (1980) Surgical Correction of Dentofacial Deformities. W.B. Saunders Co., Philadelphia, 115-123.

[36] Bean, L.R., Kramer, J.T. and Khouw, F.E. (1970) A Simplified Method of Taking Radiographs for Cephalometric Analysis. Journal of Oral Surgery, 28, 675-678.

[37] Farkas, L.G., Sohm, P., Kolar, J.C., Katie, M.J. and Munro, I.R. (1985) Inclinations of the Facial Profile: Art versus Reality. Plastic and Reconstructive Surgery, 75, 509-519. http://dx.doi.org/10.1097/00006534-198504000-00011

[38] Watted, N., Teuscher, T. and Wieber, M. (1999) Die Analyse des vertikalen Gesichtaufbaus als Planungsorientierung in der orthognathen Chirurgie. Kieferorthopaedie, 16, 29-44.

[39] Watted, N., Bill, J., Witt, E. and Reuther, J. (1998) Lengthening of the Lower Face Angle Class II Patients with Skeletally Deep Bite (Short-Face-Syndrome) through Combined Orthodontic-Surgical Treatment. Proceedings of the 7th International Symposium on Dentofacial Development and Function, Jerusalem, 15-18 November 1998.

[40] Watted, N., Bill, J., Witt, E. and Reuther, J. (1999) Lengthening of the Lower Face Angle Class II Patients with Skeletally Deep Bite (Short-Face-Syndrome) through Combined Orthodontic-Surgical Treatment. Proceedings of the 75th Congress of the European Orthodontic Society, Strasbourg, 23-26 June 1999.

[41] Carlson, D.S., Ellis, E. and Dechow, P.C. (1987) Adaptation of the Suprahyoid Muscle Complex to Mandibular Advancement Surgery. American Journal of Orthodontics and Dentofacial Orthopedics, 92, 134-143. http://dx.doi.org/10.1016/0889-5406(87)90368-4

[42] Reynolds, S.T., Ellis, E. and Carlson, D.S. (1988) Adaptation of the Suprahyoid Muscle Complex to Larger Mandibular Advancement. Journal of Oral and Maxillofacial Surgery, 46, 1077-1085. http://dx.doi.org/10.1016/0278-2391(88)90454-5

[43] Ellis, E. and Hinton, R.J. (1991) Histologic Examination of the Temporomandibular Joint after Mandibular Advancement with and without Rigid Fixation: An Experimental Investigation in Adult Maccaca mulatta. Journal of Oral and Maxillofacial Surgery, 49, 1316-1327. http://dx.doi.org/10.1016/0278-2391(91)90311-9

[44] Williamsone, E.H., Evans, D.L., Barton, W.A. and Williams, B.H. (1977) The Effect of Bite Plane Use on Terminal Hinge Axis Location. The Angle Orthodontist, 47, 25-33.

[45] Williamsone, E.H. (1978) Laminagraphic Study of Mandibular Condyle Position When Recording Centric Relation. The Journal of Prosthetic Dentistry, 39, 561-564. http://dx.doi.org/10.1016/S0022-3913(78)80194-2

[46] Williamsone, E.H., Caves, S.A., Edenfield, R.J. and Morse, P.K. (1978) Cephalometric Analysis: Comparisons between Maximum Intercuspation and Centric Relation. American Journal of Orthodontics, 74, 672-677. 
http://dx.doi.org/10.1016/0002-9416(78)90006-4

[47] Williamsone, E.H., Steinke, R.M., Morse, P.K. and Swit, T.R. (1980) Centric Relation: A Comparison of Muscle-Determined Position and Operator Guidance. American Journal of Orthodontics, 77, 133-145. http://dx.doi.org/10.1016/0002-9416(80)90002-0

[48] Williamsone, E.H. (1981) JCO Interview: Occlusion and TMJ Dysfunction. I. Journal of Clinical Orthodontics, 15, 333-350.

[49] Williamsone, E.H. (1981) JCO Interview: Occlusion and TMJ Dysfunction. II. Journal of Clinical Orthodontics, 15, 393-410.

[50] Celenza, F.V. (1973) The Centric Position: Replacement and Character. The Journal of Prosthetic Dentistry, 30, 591598.

[51] Celenza, F.V. and Nasedkin, J.N. (1978) Occlusion: State of the Art. Quintessence Publishing Co Inc, Chicago.

[52] Celenza, F.V. (1985) Physiologie und Pathologie der Kondylenposition. Internationales Journal für Parodontologie und restaurative Zahnheilkunde, 2, 39-51.

[53] Calangna, L., Silverman, S. and Garfinkel, L. (1973) Influence of Neuromuscular Conditioning on Centric Relation Registrations. The Journal of Prosthetic Dentistry, 30, 598-604.

[54] Dal Pont, G. (1959) L'osteotomia retromolare per la correzione della progenia. Minerva Chirurgica, 18, $1138-1141$.

[55] Dal Pont, G. (1961) Die retromolare Osteotomie zur Korrektur der Progenie, der Retrogenie und des Mordex apertus. Österreichische Zeitschrift für Stomatologie, 58, 8-10.

[56] Obwegeser, H. and Trauner, R. (1955) Zur Operationstechnik bei der Progenie und anderen Unterkieferanomalien. Deutsche Gesellschaft für Zahn-, Mund- und Kieferheilkunde, 23, 1-26.

[57] Obwegeser, H. (1957) The Surgical Correction of Mandibular Prognathism and Retrognathia with Consideration of Genioplasty. Oral Surgery, Oral Medicine, Oral Pathology, 10, 677-689. http://dx.doi.org/10.1016/S0030-4220(57)80063-2

[58] Obwegeser, H. (1963) The Indication for Surgical Correction of Mandibular Deformity by Sagittal Splitting Technique. British Journal of Oral Surgery, 1, 157-171. http://dx.doi.org/10.1016/S0007-117X(63)80067-0

[59] Ellis, E. (1994) Condylar Positioning Devices for Orthodontic Surgery: Are They Necessary. Journal of Oral and Maxillofacial Surgery, 52, 536-552. http://dx.doi.org/10.1016/0278-2391(94)90085-X

[60] Lindorf, H.H. (1984) Funktionsstabile Tandem-Verschraubung der sagittalen Ramusosteotomie-Operationsthenik, neue Instrumente und Erfahrungen. Deutsche Zeitschrift fur Mund-, Kiefer-, und Gesichts-Chirurgie, 8, 367-373.

[61] Lindorf, H.H. (1986) Sagittal Ramus Osteotomy with Tandem Screw Fixation-Technique and Results. Journal of Maxillofacial Surgery, 14, 311-316. http://dx.doi.org/10.1016/S0301-0503(86)80314-9

[62] Michel, C. (1990) Zur Problematik der Gelenkposition in der orthopädischen Chirurgie des Kiefergesichtsschädel. Medizinische Habilitation, Würzburg. 